\title{
Beating time, gesticulating and dancing
}

The role of the choir director in the BAPRESCA choirs in Cameroon

\section{Nepomuk Riva}

Translator. Maggie Jones

\section{(2) OpenEdition \\ Journals}

Electronic version

URL: http://journals.openedition.org/transposition/1283

DOI: $10.4000 /$ transposition. 1283

ISSN: $2110-6134$

\section{Publisher}

CRAL - Centre de recherche sur les arts et le langage

\section{Electronic reference}

Nepomuk Riva, « Beating time, gesticulating and dancing », Transposition [Online], 5| 2015, Online since 22 November 2015, connection on 30 July 2019. URL : http://journals.openedition.org/ transposition/1283 ; DOI : 10.4000/transposition.1283

This text was automatically generated on 30 July 2019.

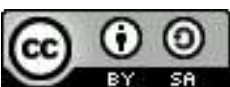

La revue Transposition est mise à disposition selon les termes de la Licence Creative Commons Attribution - Partage dans les Mêmes Conditions 4.0 International. 


\section{Beating time, gesticulating and dancing}

The role of the choir director in the BAPRESCA choirs in Cameroon

\section{Nepomuk Riva}

Translation : Maggie Jones

\section{AUTHOR'S NOTE}

The illustrations were produced by the author based on video footage recorded in the field.

1 For the Presbyterian Church in Cameroon choir organisation, BAPRESCA, the religious year culminates in a choir competition bringing together more than twenty co-ed choirs from different parishes. In an event spanning several hours, these choral ensembles from the Bakossi region in southwest Cameroon present in turn a hymn of some length in the regional language, Akose. The judges and the audience appraise not only the singers' musical skill, but also their attitude during the performance, with particular attention on the choir directors, who are fully aware of their importance.

2 The 2008 choir competition, held in the town of Tombel, offered the opportunity to observe and identify a variety of choir conducting techniques. Some directors simply beat time or marked the rhythm of the melodies, cueing the different sections of the choir with hand signals. For their choirs, it seemed important that they control the course of the song. 


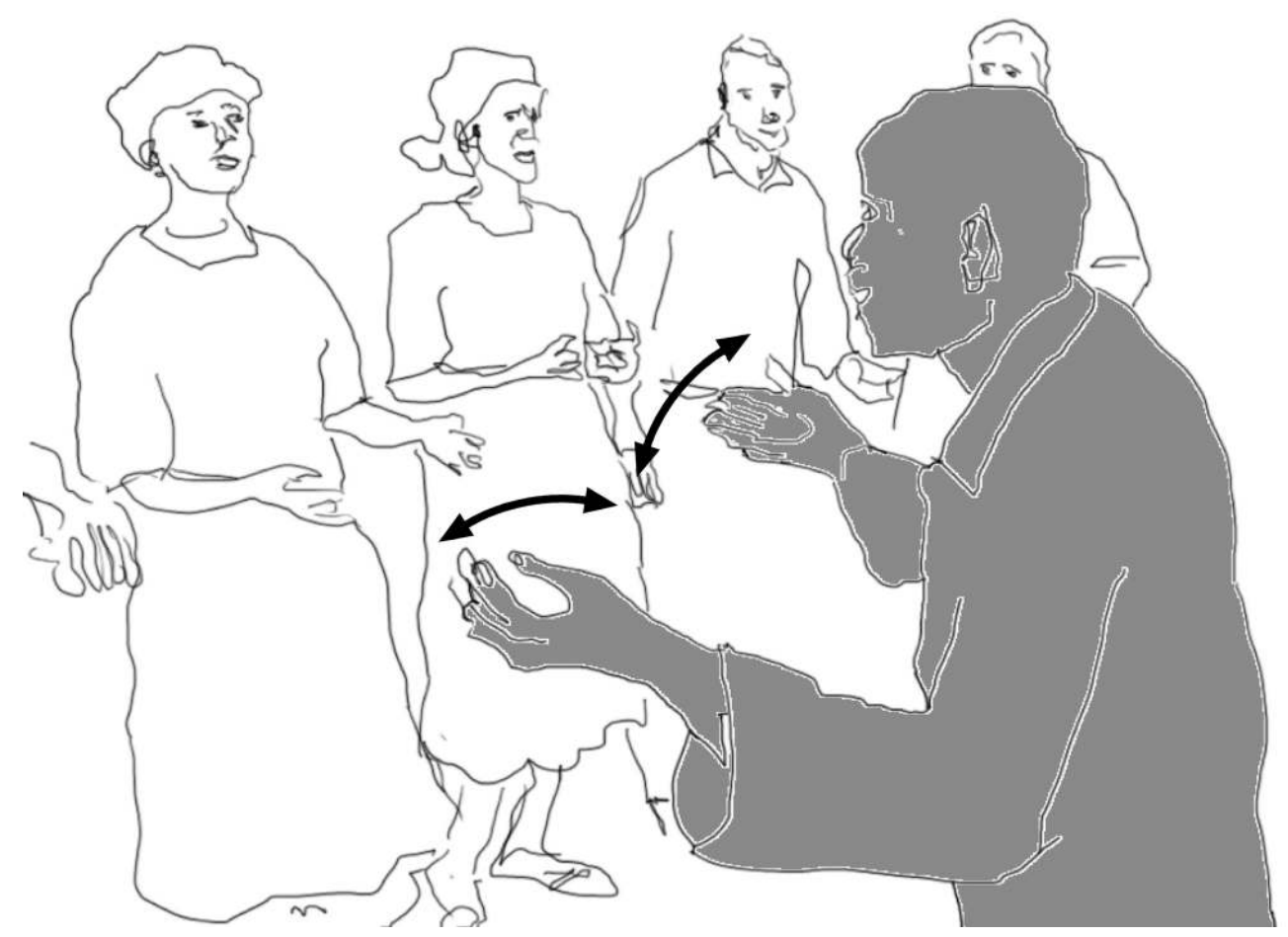

3 Other female directors swayed and wagged their bodies to the music, swinging their arms and singing along with the choir. In this case, the members of the choir had to know the melody and words by heart in order to stay on course simply by following the choir director's body movements. They could mimic her dance movements and experience the song corporally.

\section{2: Dance movements of the choir director (and singers)}

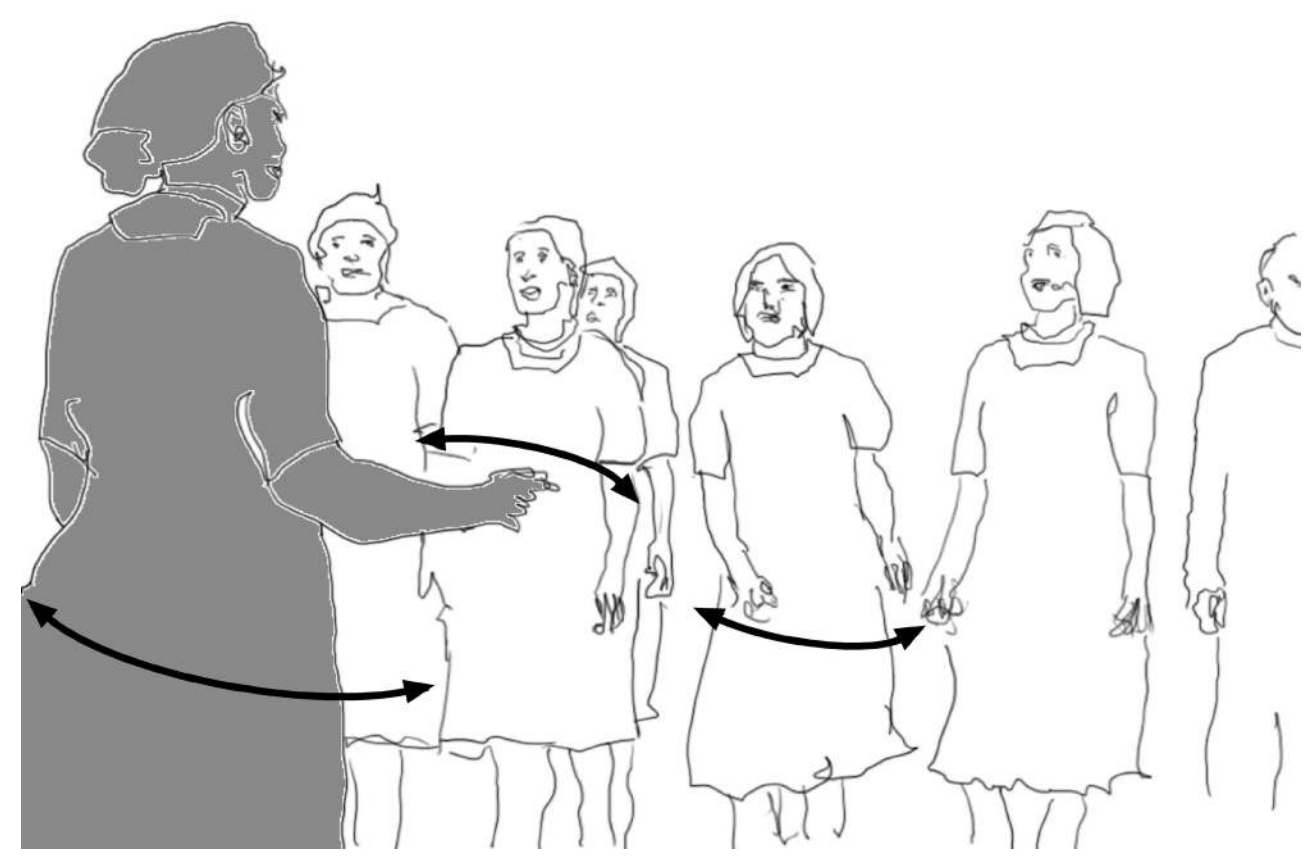


4 Still other directors, in addition to guiding the singing, also enhanced their conducting with gestural prompts, or "illustrators", emphasising the content of what was being sung, providing the choir with reminders of the next words to sing.

\section{3: The choir director's gestural prompts illustrating the word "speak" to the choir}

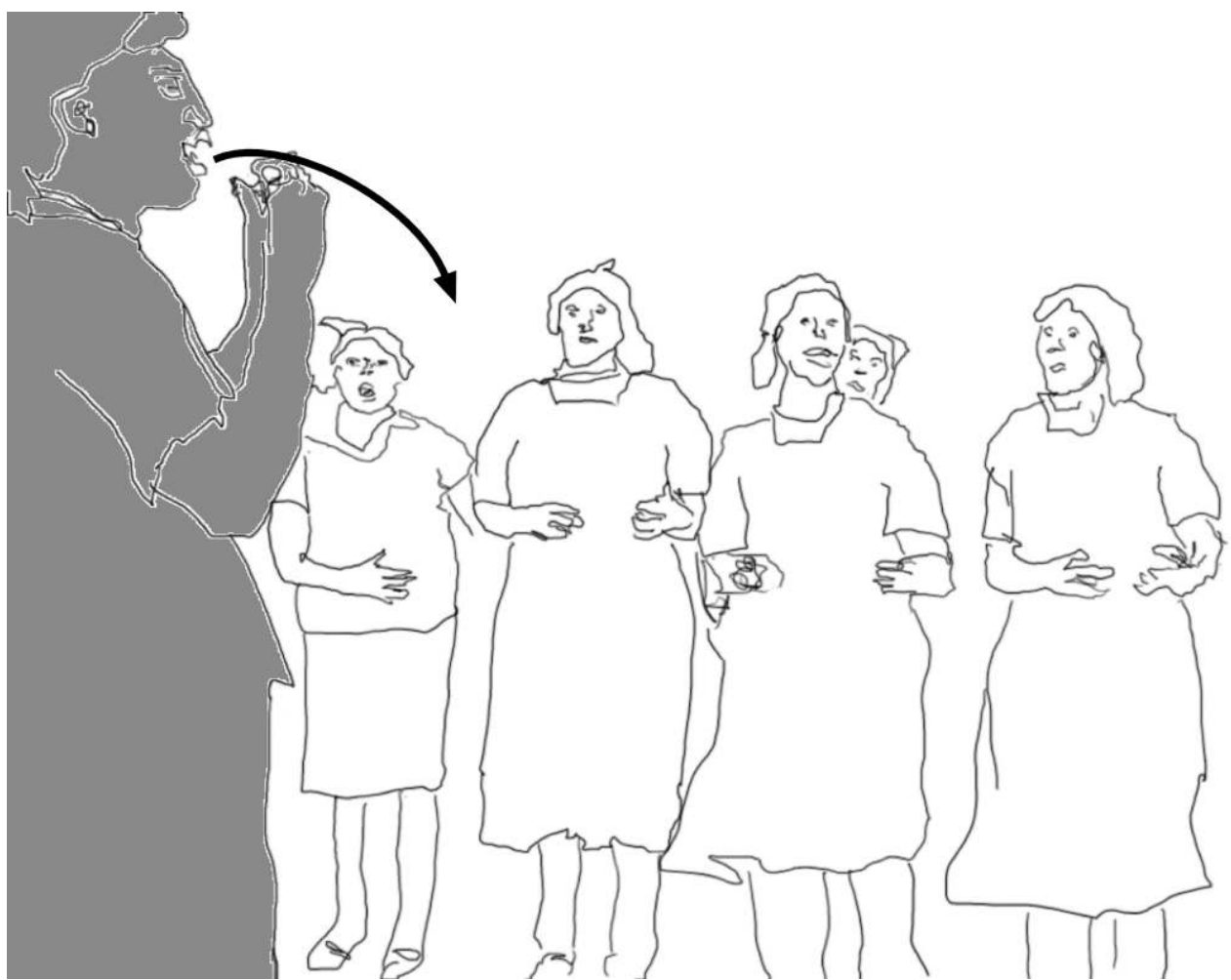

5 At the end of their song, directors willingly switched roles, having the choir repeat a simple melodic pattern over which they sang a solo. For this part of the presentation, they would turn to face the audience, using iconic gestures to drive home what they were singing. 


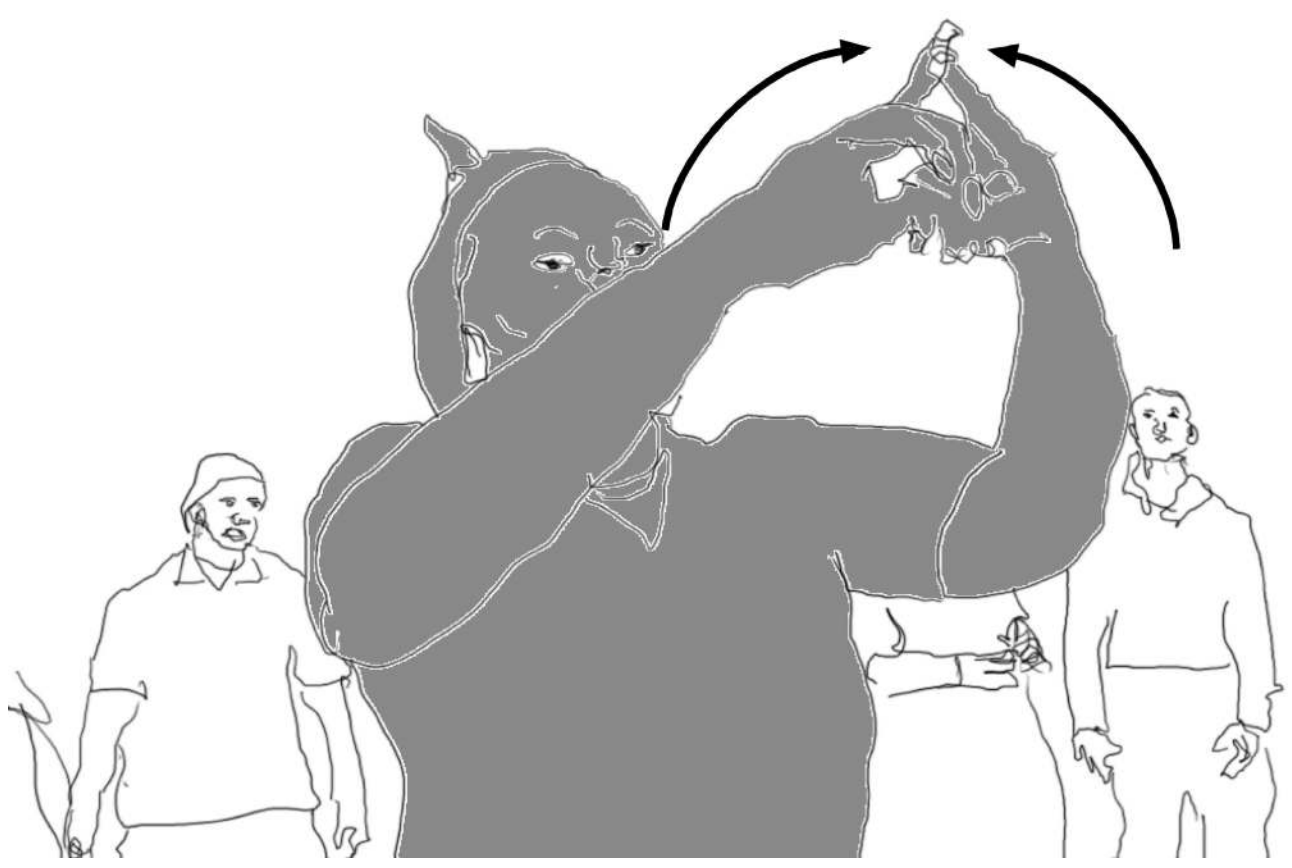

6 This last performance technique is the one that consistently most pleased the crowd, made up almost exclusively of members of other choirs.

This type of regional competition between the BAPRESCA choirs has only been taking place for several years. The contests were started by two friends, Paul Epie Mesumbe and Rey Njume Etone, both composers, who since the 1980s have created choirs in a number of parishes in the Bakossi region, all of which learn and perform a repertory entirely in the Akose language. ${ }^{1}$ The practice of singing in co-ed choirs dates as far back as the Christian mission, which became an established presence in Cameroon at the end of the nineteenth century. The missionaries, who had no musical training to speak of, introduced the collective singing of European hymns in the parishes they founded, an activity which the natives enthusiastically embraced. Through imitation, the Cameroonians assimilated the role of choir director, which is not something that existed in their precolonial musical practice. However, over time, the role of choir director in Cameroon evolved on its own, no longer connected to the original model provided by the European missionaries and the musical tradition of the West. It was adapted to the style of traditional music and incorporated new aspects in order to fit the needs of Cameroonian singers.

The evolution of the role of the choir director in Cameroon is a multi-faceted field of study which ultimately offers a new perspective on this musical function: we will see the extent to which choir conducting, in practice, depends on the concrete musical and cultural traditions and circumstances, as does the singers' comprehension of forms of corporal expression.

While there have been many studies on the emergence of neo-African church music in the twentieth century, ${ }^{2}$ there has been very little research on how this music is executed in practice, including how the choir is directed. ${ }^{3}$ In the following pages, I would first like to chronicle the introduction of the choir director function in Cameroon, and which precolonial musical traditions were subsequently incorporated into the way it is 
employed. Then, taking the example of the BAPRESCA choir organisation, I will set out the basic conventions in how it is practiced. BAPRESCA is an organisation I have accompanied on a regular basis, for a variety of occasions, since 2003. ${ }^{4}$ It is an appropriate subject for a case study in that the member choirs sing in the same Cameroonian language, their uniform repertory developed independently from European church music, and the members are from similar social backgrounds. Finally, we will explore the question of how this system of gestures can be communicated and transmitted.

\section{Choir conducting practices in Mission music and precolonial influences}

Following the colonisation of Cameroon by the Germans in 1884, the Basel Mission claimed the country as a territory for evangelisation, taking over from the English Baptists who had founded Christian parishes along the coast decades earlier. Missionaries from southern Germany and Switzerland penetrated into inland areas where they founded rural parishes, schools and social institutions. To run and maintain these structures, they immediately enlisted catechists, ancillary staff and teachers from the native population. Within a few years, the ecclesiastical life-and consequently, the musical practice-was largely in the hands of Cameroonians, although their activities were overseen to some degree by Europeans. With the outbreak of World War I, the Basel Mission had to withdraw from Cameroon. The German colony, occupied by the English army from Nigeria and the French army from French Equatorial Africa, was divided along the former frontline into an English-speaking region and a French-speaking region. The Basel Mission was not allowed to return to Cameroon until 1926, and then only to the western, English-speaking part of the country. Meanwhile, a Roman Catholic missionary organisation from France, Société Missions Etrangères de Paris, assumed control of the Christian parishes on the French side. To the great surprise of the Swiss missionaries, when they returned to the country they found that the Christian parishes had grown, although during the Missions' absence they had incorporated their own cultural adaptations into the religious practices. In 1957, the missionary church on the English side of the country became an independent entity called the Presbyterian Church in Cameroon, or PCC. ${ }^{5}$

11 The changes in the political situation were reflected in the school system, which was the primary source of musical training. In the first schools created by the Mission, music was taught by the missionaries and teachers themselves, and music education generally consisted in collective singing and learning European hymns by heart. ${ }^{6}$ Pupils were not taught how to read notated music. ${ }^{7}$ Some members of the Mission found early church songs written by natives worthy of mention in their writings. ${ }^{8}$ The music education offered by State schools was no more extensive. In isolated cases, certain teachers took great interest in the Cameroonian music techniques, such as Rudolf Betz who closely studied the Douala drum languages. ${ }^{9}$ Coming under British rule meant the British colonial school system was introduced, bringing with it the teaching of music theory based on John Curwen's method, Tonic Sol-fa. This system of musical notation is still today the most widely known among literate Cameroonians, but it does not seem to ever have been taught systematically. ${ }^{10}$ The Basel Mission did not incorporate the Curwen method into its musical practices and continued using simple hymn books without musical notation. Even now, there is still no higher education institution offering formal music training 
anywhere in Cameroon. In many regions, Christian churches with their various choir groups are the hub of musical activity. Each year, different denominations offer paid vocational development courses where trainees can learn the basics of music theory and notation. However, a school diploma is an implicit pre-requisite to attend these courses, which excludes many members of the Church. The art of choir conducting is not part of the curriculum, although the practical workshops include a lot of singing.

Because of the vastness of the territory, the difficulty of getting an accurate general overview, the relatively low population density, and Cameroon's linguistic and political diversity, simply setting up parishes was often all the missionaries could do. It was impossible to oversee the organisation of Christian life in each of the many villages, such that "relapses into paganism" are mentioned in official Basel Mission reports as positive descriptions, indicative of an especially vibrant musical life, with independent choirs singing their own hymns with multi-part harmonies. ${ }^{11}$ The reports also sometimes mention the use of indigenous instruments, such as drums, in honour of the missionaries - at least outside the church building. ${ }^{12}$ However, very little is said about how this music was rehearsed and executed. Choir directors are sometimes alluded to, but missionaries seldom address how they specifically carried out their function in practice:

Even though it was night time, we found the chapel filled with young people. [...] Our station's entire territory is full of this type of singing association. All the young people in a village gather three or four times a week to rehearse by lamp-light, under the direction of an additional leader, four-part choirs in the presence of the teacher and an elderly member of the church. [...] The songs they learn, which are partially written and composed by the Blacks themselves even though they know nothing of musical notation or the rules of composition, are sung in order to enrich and enhance the church service each Sunday. ${ }^{13}$

We learn only in passing that when during native musical presentations, certain figures may also assume the role of music director. Persons with functions similar to that of a choir director are also mentioned in the description of a ritual in which, under the Mission's influence, a secret society forswears its magical practices:

The entire assembly [members of the parish] is arranged by section, with a leader in front of them. Two people are already poised to beat the big drum with their fists, and another is positioned near a dance drum. Everything is in place for the show to begin. But no one else has turned out, out of fear of Disio (the Bakoko call the spirit of the secret society Disio). Only a handful of Christians are with us, and everyone is waiting to see what is going to happen. The leader waves his stick and begins the show with a short song. When he gives the signal, the entire group joins him in singing and striking the instrument with all their energy in every direction, as fast and as loudly as possible. The director falls to the ground and quickly gets up again. He gives the signal to end this great spectacle. The idyll Disio has made his voice heard for the last time. After a last battery of pounding on the brand new drum-it cost 40 Marks-the playing stops. This is the secret of Disio. ${ }^{14}$

14 In this description, it is not clear whether the person in front of the others sings, plays the drum or dances. But the role of this person is explained in more detail in this account of a baptism celebration, written by a nurse named Lina Weber in 1946:

After the baptism, as we celebrate the communion with the new members of the parish, the others gather in front of the church, some with musical instruments and others bearing branches and leaves they have stripped from the pretty bushes all around the church, leaving them quite bare. Then begins a spectacle so delightful that it is almost impossible to pull oneself away. Playing music, singing and dancing all the while, the congregation leads the newly baptised outside the church for a time, before our astonished eyes, and then to the village square, where the 
celebrations gets into full swing. Men, women, children, mothers with children strapped to their backs and fathers with children in their arms-everyone is following the sounds of the music and joins in singing a song led by she among the women who sings and she who dances in front of the others. The only words I manage to understand are those that are constantly repeated, "Sango Yesu" and "Hallelujah". ${ }^{15}$

The allusion to these two women, "she among the women who sings and she who dances in front of the others," leads one to wonder whether the Christian mission was really the only model that influenced the function of choir director, or if there were multiple models in precolonial musical culture that helped shape this function.

With regard to singing, here we must mention the figure of the first singer, which plays an important role in musical practice in Cameroon. Many orally transmitted songs were, and still are today, constructed on the basis of a call-and-response technique, which means that in order to be sung, a person in the role of leader must musically guide the group. ${ }^{16}$ When first person begins to sing a verse, she chooses the song and sets the pitch and tempo, yet also very audibly takes part in the interpretation. This is different from the role of the first dancer-a figure that also appears in the missionaries' reports, especially in association with funeral ceremonies (which last several days). ${ }^{17}$ The first dancer indicates the body movements that correspond to a specific piece of music, also serving as the model whose movements the group mimics simultaneously. This person's movements therefore seem to serve as silent indications, accompanying the music without being commands. Forms of expression that involve dance-such as clapping along, shaking palm branches, or wagging certain parts of the body-are part of a repertory used to communicate the meter and rhythm of the music. ${ }^{18}$ Finally, we must also mention the first drummer who, in certain drumming groups, indicates the rhythm that determines the style and tempo. As in the case of the first singer, this musician plays the role of leader while also taking part in the presentation. The figure of the first drummer probably had little influence on the practice of religious music, as drums were rarely used in Mission church services. This was not because the missionaries had forbidden the use of drums, but rather that in this region of Cameroon, drums could only be played by men (with rare exceptions), and far fewer men than women were involved in church music. In terms of language-based communication, it is interesting that the early missionary reports refer very frequently to the pronounced gestures used by the natives when speaking, and texts defining the grammar mention gestural signs that replace certain words. ${ }^{19} \mathrm{~A}$ colonial civil servant named Hunter noted in his report that the phenomenon of gesticulating went as far as to include a gestural language that transcended the dialectical differences in Cameroon and played an important role in communication, especially in commerce. ${ }^{20}$ While the sources do not provide a detailed analysis of gesticulation, they do make it clear that hand gestures fill an important function in communication, and that they can also be used in music, as missionary Johannes Ittmann describes in his account of a funeral ceremony:

Each dancer makes his own movements on the square. At first, one sees only a confusing jumble. But one you have been educated about the movements, you see that the dancers are trying to show the visible and invisible spectators how they support and feed their tribe. The closest relatives of the deceased try to show by every possible means what a rich and respected man he was. They glorify themselves, so to speak, with his wealth. One sings while dancing, "Show me a virgin, so I can start making payments on her price today or tomorrow!" Beside him, one dancer embraces another and while they spin together sings, "If I weren't 
holding you tightly, you'd go mad from so much wealth!" [...] Nearby, another dancer holds his hands open beneath his nipples, signifying that he has daughters to marry. ${ }^{21}$

\section{Diversity in music conducting practices between different cultures}

17 As we have said, we do not have detailed sources about music conducting in Cameroon during the Mission era. As we cannot identify a clear model dating back to precolonial musical practice, it seems unwise to try to make historical comparisons with the Western form of conducting. Rather, we shall consider the phenomenon of music conducting in a systematic manner.

18 Let us first specify four key factors that led to the conductor becoming a permanent fixture in European music in the nineteenth century: 1) the growing size of choirs and orchestras made a central leadership position necessary; 2) the complexity of the music required the presence of a conductor who was capable of supervising everything; 3 ) there needed to be a perceptible way of commanding all of the musicians with regard to the musical style, particularly the frequent changes in dynamic and tempo; and finally, 4) the person conducting the musicians had to be inaudible in the execution of the work. These four criteria gave rise to the function of the orchestra conductor, who is positioned such that he is visible to all of the musicians in the orchestra, and who guides them through the work when they perform it. To give his indications, he refers to a score according to which he cues the musicians' entrances and signals the rhythm, tempo and changes in dynamic. All of this, he does using a soundless technique made up of gestures, movements, facial expressions and body language. ${ }^{22} \mathrm{His}$ duties also include rehearsing the works with the musicians before they are executed for an audience; in a rehearsal setting, he is allowed to use speaking, singing and other acoustic stimuli, such as clapping his hands or audibly beating time. Essentially, the aim of the rehearsal process is assimilation of a given interpretation of a musical work, as all of the musicians have the notes to their part in front of them, and these notes are generally immutable. ${ }^{23}$

Compared to orchestra conducting, the demands of conducting the BAPRESCA choirslike most other Cameroonian village choirs-are quite different. However, since the practice of choir singing as introduced by the Christian church involves multi-part harmonies and fairly long songs, there does need to be a leader guiding the others. Evidence suggests that in the Bakossi region, the collective songs of the precolonial era were, on the contrary, monophonic and marked by short melodic patterns. Moreover, the musical genres were differentiated by gender, and representative musical forms existed only within elite "secret societies". ${ }^{24}$ Collective singing developed for social or religious reasons and although it included a fixed repertory, it was in many ways characterised by improvisation. The musical practice which consists of composing songs, rehearsing them and then presenting them at religious services does not correspond to any precolonial interpretation. Moreover, the way singers form a circle when singing what are still referred to as "traditional" songs shows how little hierarchy there is within the group, unlike in church choirs which are always arranged in rows, facing front.

Given that women make up the large majority of the members of the parish and the choir, and that many of them are illiterate, the first step for the person directing them during the preparatory phase is to teach them the words of the song and the melody. The 
practicing done during rehearsals has to allow the singers to sing the songs completely from memory during public presentations. If they run into any difficulties, the choir director needs to be able to remind them of both the lyrics and the melodic motion. Choir directors also may need to be able to actively take part in the singing. On the other hand, directors do not need to spend much time going over the harmony parts, as over many years of singing church music, the Cameroonian choirs singers have become well-versed in harmoniously singing multiple voices with melodies they know. They have no problem forming an alto or tenor voice at the third or sixth interval for a familiar melody, and the bass section is capable of completing all heptatonic melodies with appropriate harmonic notes in the three basic harmonies (tonic, dominant and subdominant). Thus, conducting the choir in collectively singing the melody depends on how the song has been technically composed: if the melodic motion conforms rigorously to the form of the text, with linguistic accents and long or short syllables, then the free rhythm must be made very obvious; if a meter is specified for singing over an isorythmic melody, simply beating the meter is enough, and dance movements can even be used. By accompanying the music, dance movements allow the choir director to feel within her own body whether or not the song is being sung at the proper tempo. The songs in the BAPRESCA choir repertory culminate with the soloists' parts, which come in to join the rest of the voices. The most talented singers, male and female, are chosen to sing solos, and the importance of their role-and thus the high expectations for their vocal interpretation-often mean that the role of choir director goes to the female soloist rather than person with the most musical training and education.

21 To better understand the specific challenges faced by BAPRESCA choir directors, let us take a closer look at several different church music rehearsal and presentation situations. In doing so, based on research by David $\mathrm{McNeill}^{25}$ and Adam Kendon ${ }^{26}$ on gesticulation, we can consider gestures, speaking and singing as equivalent components of a message. The basic categories distinguished by McNeill-iconic, metaphoric, deictic and rhythmic ${ }^{27}-$ can be identified in the corporal expression used by the choir director, although certain movements take on a special meaning because they are tied to musical aspects. Finally, we will see that Cameroonian choir conducting gestures allow us to identify not only certain gestural systems that operate according to different regularities-such as chironomy, deictic gestures or rhythmic and metric beats-but also emblematic gestures that convey meaning and can be used in a prescriptive manner.

\section{The conducting techniques of BAPRESCA choir directors}

The BAPRESCA choirs, made up of around 10 to 25 people, assemble one evening per week for a rehearsal which is largely geared towards people who do not know how to read. To help promote effective memorisation, several songs from the repertory are sung at the beginning and end of each session, to refresh the singers' memory of the words and melody. New songs are studied in a linear manner, verse by verse: the choir director sings each melody one by one, segment by segment, from the soprano part to the bass part, and the members of the choir repeat them as many times as necessary until everyone has learned them. Then the entire song, which is several minutes long, is sung several times through. In each section of the choir, a singer who has a particularly solid grasp of the song guides the others by singing more loudly, so that the less experienced singers can 
follow her lead. Thanks to this mixing of singers of different abilities, almost no work on changes in dynamic is needed.

As no sheet music is used, in order to teach new melodies, the director uses a chironomic system in which the pitch of the notes is indicated with deictic gestures on a vertical axis.

5: Rehearsal situation with chironomic gestures (Tombel, 2008)
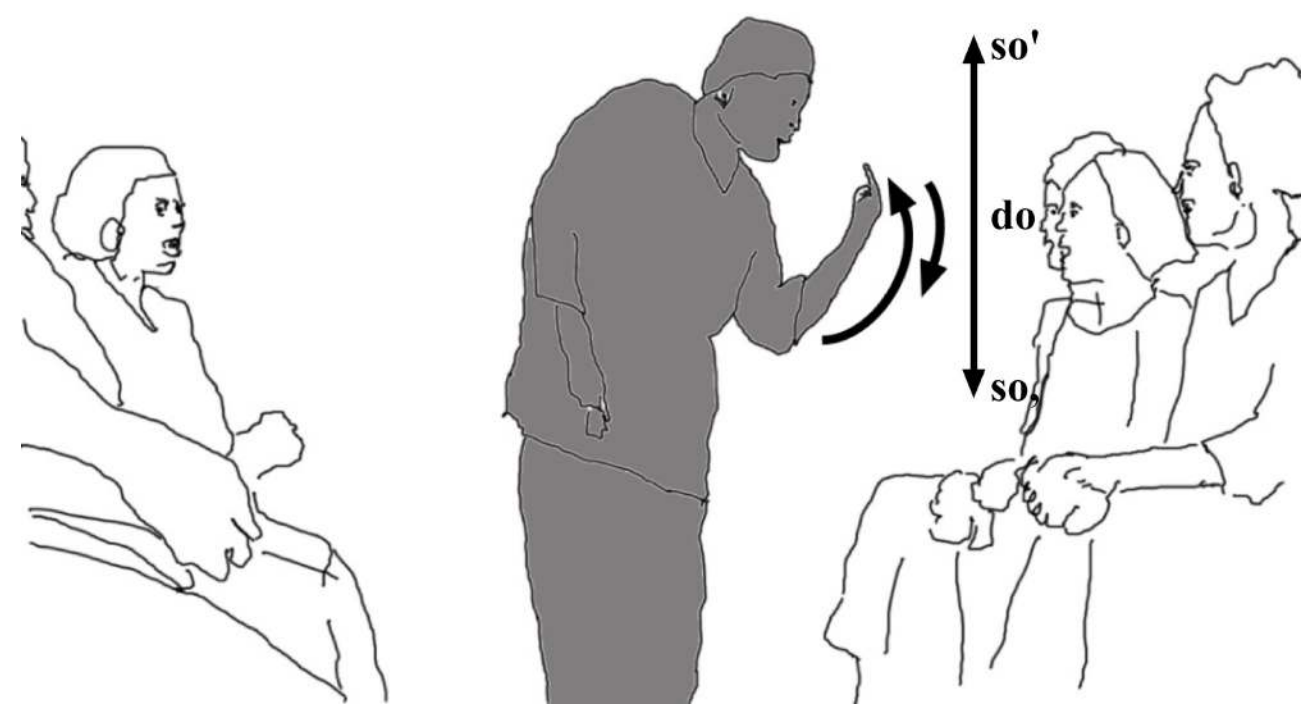

High notes are indicated high on the axis and low notes low on the axis, without always needing to move the entire arm as the index finger is enough to point to the note. With this system of gestures, the director metaphorically creates a column of sound with her movements. The members of the choir also receive a visual image of the melody, even if it is only fleeting. Notes are never indicated horizontally in Cameroon. The members of the Presbyterian Church in Cameroon are not familiar with the spatial representation of melodic motion as we know it in the West, by analogy with graphic notation. Based on my own experience, I do not think they would know how to interpret it.

During the rehearsals, the choir director fills the function of "first singer", but not in the manner of call-and-response singing: she merely introduces the melodies for learning purposes, but will not sing them later when the choir sings publicly. The emergence of the chironomic gesture system can be clearly retraced, with evidence suggesting that it developed during the Mission era and with schooling. In precolonial music, there notion of a range of tones did not exist, as melodies had to strictly conform to the linguistic sonorities of the Bantu languages. ${ }^{28}$

The parishes of the Presbyterian Church in Cameroon generally include a number of subgroups. In addition to women's groups, men's groups and youth groups, they have several choirs (the number varies from one place to another) which sing in the languages of the various ethnic groups represented, or in French or English-the country's official languages. Like the BAPRESCA choirs, these choirs are interconnected through regional or national organisations. The choir that sings in English has a more elite status, as it is the only one to sing international church music composed according to the Tonic Sol-fa system. Every choir has its designated place in the nave of the church and insists on singing at least one song at every religious service. Thus, each week, the BAPRESCA choir director chooses a song that will be sung to the congregation at the beginning of the service from the choir's designated place in the pews. The director takes his or her place 
in front of the group which sings facing the altar, but does not use any chironomic gestures or play the role of director. During this collective polyphonic singing, the director's role is simply to guide the choir with rhythmic and metric gestures for the duration of the song. It is striking to see that the rhythm beating movements commonly seen in the West are not at all known in Cameroon, and that a right-to-left swinging movement has been adopted instead.

6: Choir director using rhythmic and metric gestures for a song during a church service (Nyasoso, 2004)

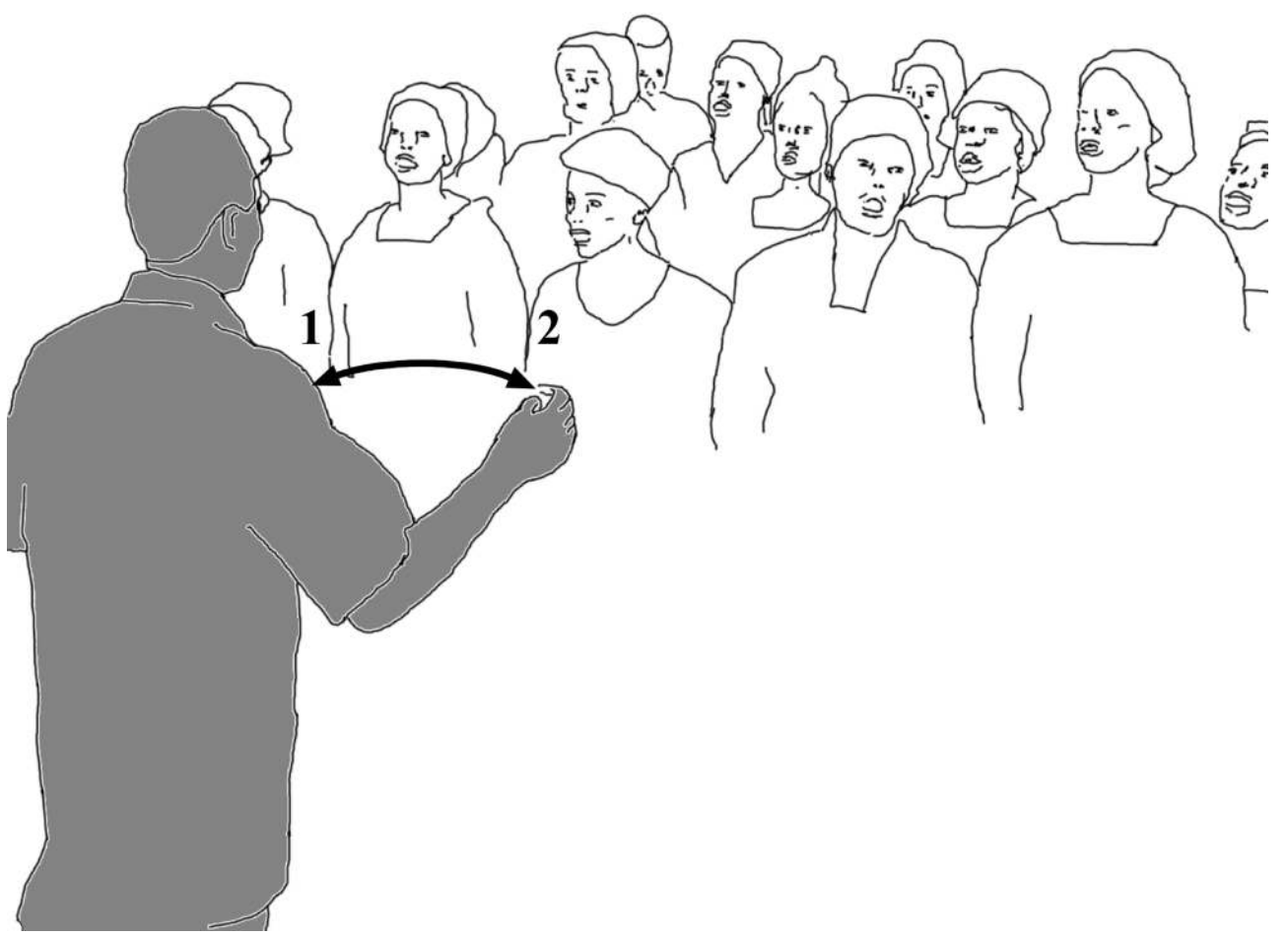

This swinging movement follows the rhythm of the melody or is used to regularly mark the meter, creating a metaphorical horizontal bar in which certain sounds or metric impulses are emphasised. This model of movement may have developed from practices such as those mentioned earlier-waving the palms or clapping the hands-or from a sort of drum beat. In this swinging movement, there is no difference in meaning between the two sides. The measure is not divided into accented and unaccented beats, but rather into long and short sounds.

In addition, the choir director also cues specific sections of the choir for their respective entrances, which he or she indicates with deictic gestures towards the persons concerned. 
7: Choir director using deictic gestures signalling the entrance of a particular section of the choir for a song during a church service (Nyasoso, 2004)

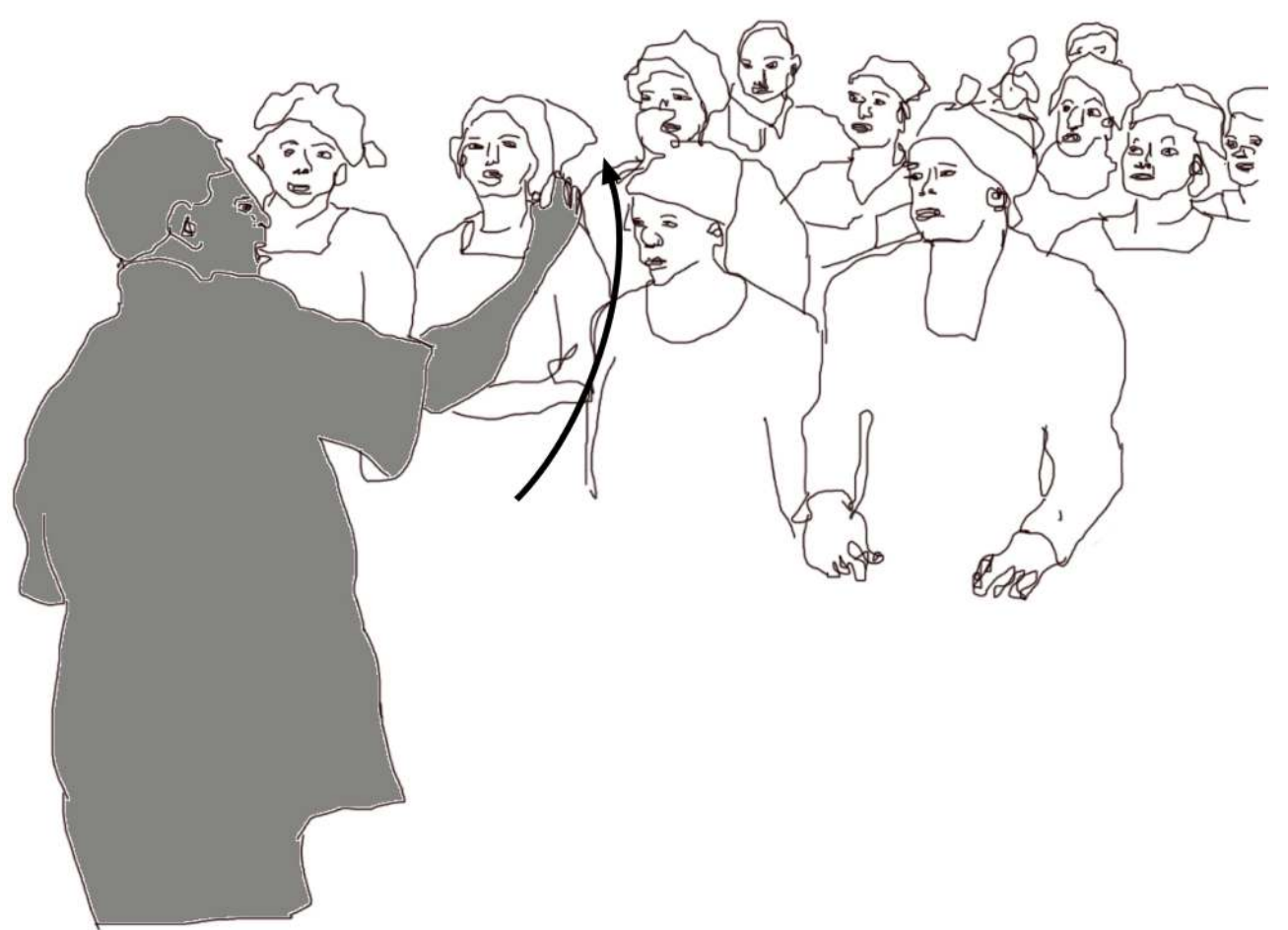

Sometimes the singers need visual reminders to help them remember the words to the song, in which case the choir director adds iconic gestures to the rhythmic and metric gestures: for example, for the phrase "God in heaven", the director raises his hands.

\section{8: Choir director using iconic gestures for the words "in Heaven" for a song during a church service} (Nyasoso, 2004)

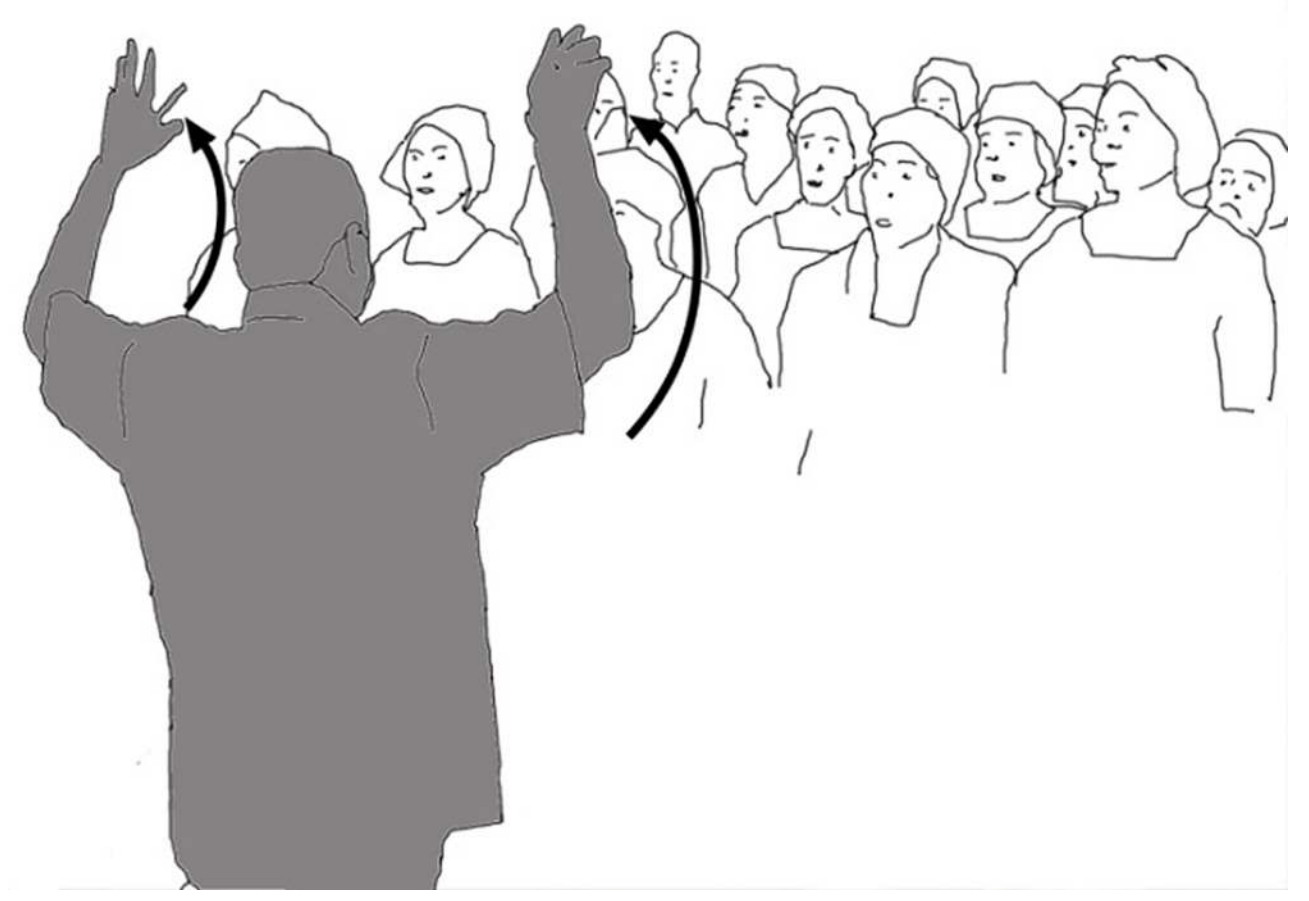


urch music circles, there is a conventional repertory of about thirty gestures of this kind that every member of the community can read and understand, providing a means of non-verbal communication during public presentations. According to the tests I have conducted during my field research trips to Cameroon, the members of the BAPRESCA choirs are able to identify the song they are going to sing simply by seeing a few of these gestures.

Thus, the director uses conventional gestures that Cameroonians know from their everyday lives, re-appropriating them in this musical context. The significations of these gestures remind the singers of the words of the song, which in turn triggers their memory of the melody so that they are able to sing it. This system of gestures is different from the hand signals commonly used by Western choir directors-such as placing the index finger against the lips to bid singers to sing more softly-in that it refers to the words of the song rather than a musical parameter.

The presentations at the annual choir competition referred to above-in which all of the BAPRESCA choirs gather at a designated location within the Bakossi region for a weekend -are distinctly different from the choir singing that takes place during church services. First, during their presentations for the competition, the choirs stand in front of the altar facing the assembly, and thus find themselves in a performance setting. Another distinction is that the groups are not competing with choirs of different styles-unlike in their home communities where there may be rivalry between different types of local choirs; rather, they find themselves up against fellow competitors very much like themselves, sometimes even singing the same songs. Each group carefully prepares their presentation and develops specific choreographies for the songs they sing in order to stand out from the others. This leads to much greater use of dance movements by both the director and the members of the choir, particularly for melodies with a regular meter. Moving hips and arms horizontally, bending the knees, and side-stepping to the right and left are key features of this stylistic aspect of the presentation.

\section{9: Choir competition performance with dance movements by the director and the members of the} choir

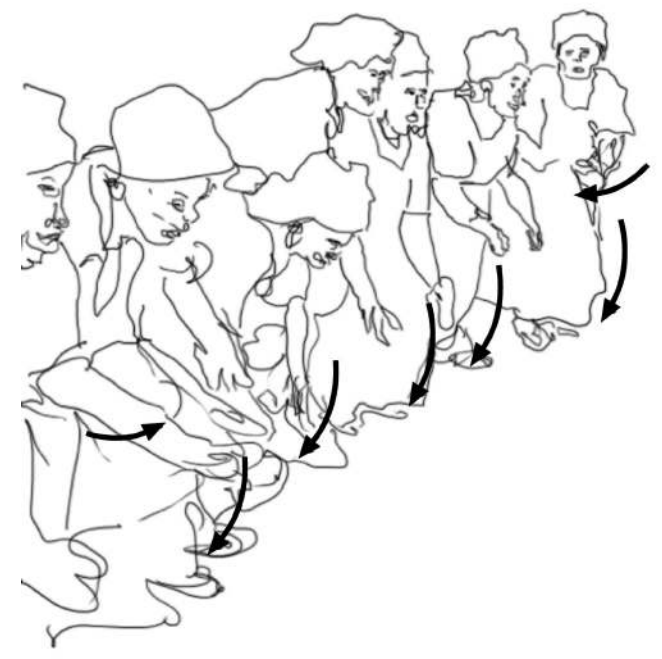

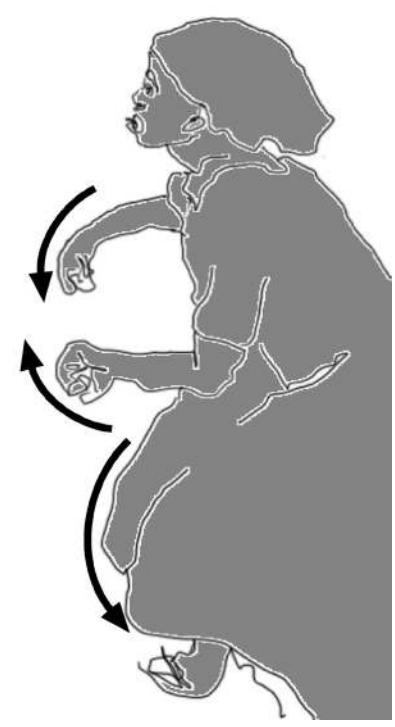



gestures corresponding to the words of the song, which the director and choir members also execute in sync.

10: Choir competition performance with the choir director's prompting gestures illustrating the word "written". The right hand is miming the pencil and the left hand, the paper

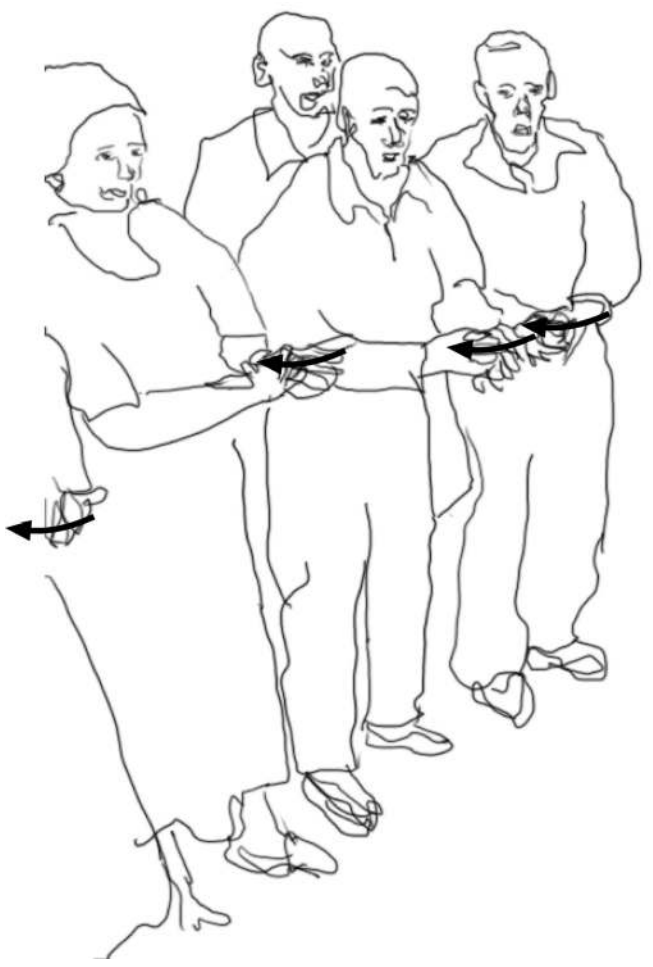

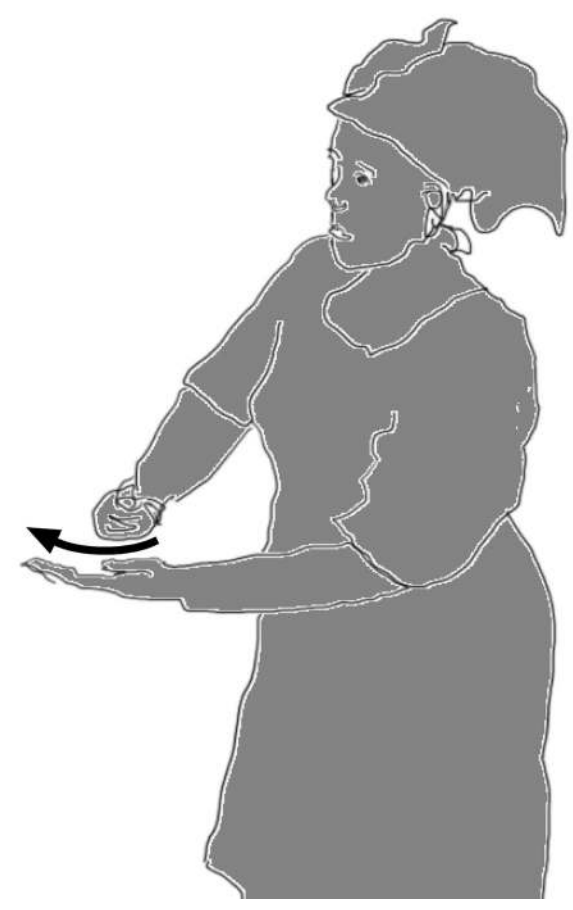

In this context, the choir director acts as a sort of "first dancer".

In March 2012, I had the opportunity to spend a week with a selection of choir directors and female singers in the city of Kumba, accompanying them during their rehearsals and recording sessions for a $\mathrm{CD}$. The choir, which had been composed specifically for this occasion, met for several days to practice the songs the singers already knew and learn others that were new to them. On the last day, twelve of these songs were recorded in the local parish's hall. During the rehearsals for the new songs, I observed that a fairly uniform conducting style is maintained in the BAPRESCA choirs. When teaching the choir a new song, the composer Rey Njume Etone accompanied each note in the initial melody presented especially slowly and moderately-with a specific hand gesture. He alternated the position of his hands-palms down and palms up-with each note, while raising and lowering his arms along a vertical axis. 


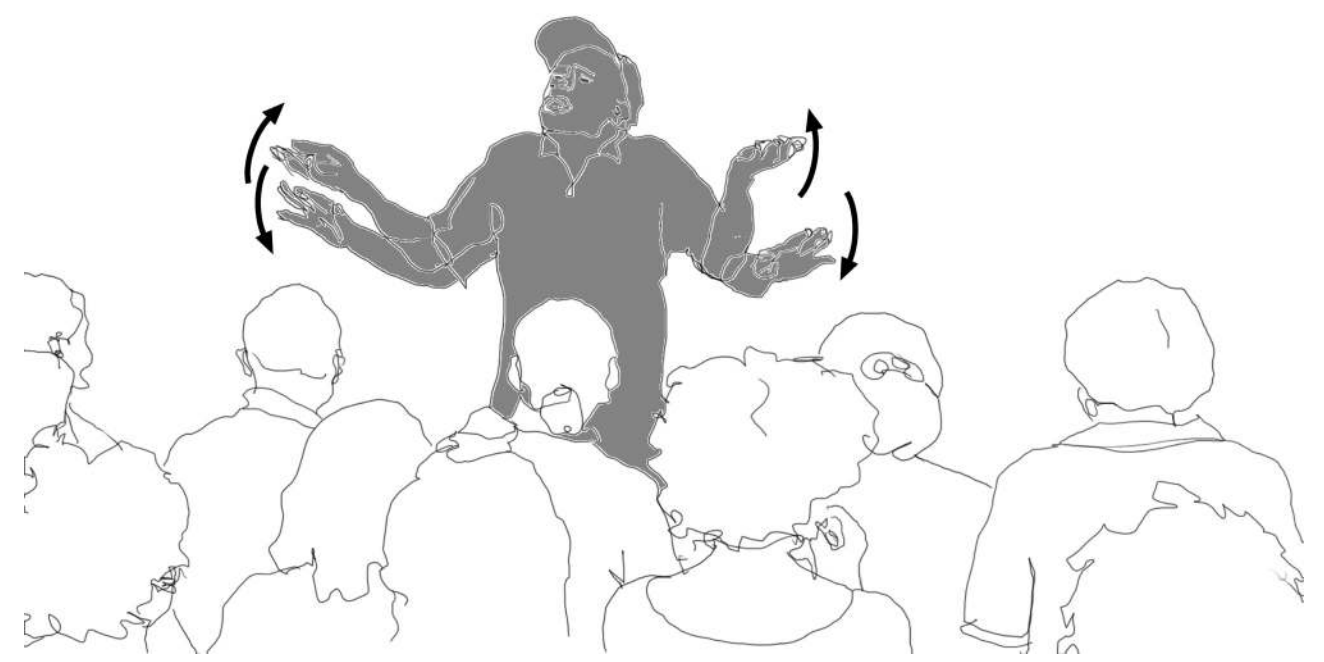

The following day, a young female choir director, who had learned the song in this manner, went over it again with the group using the same unique conducting style.

12: Use of the composer's gestures by a female choir director

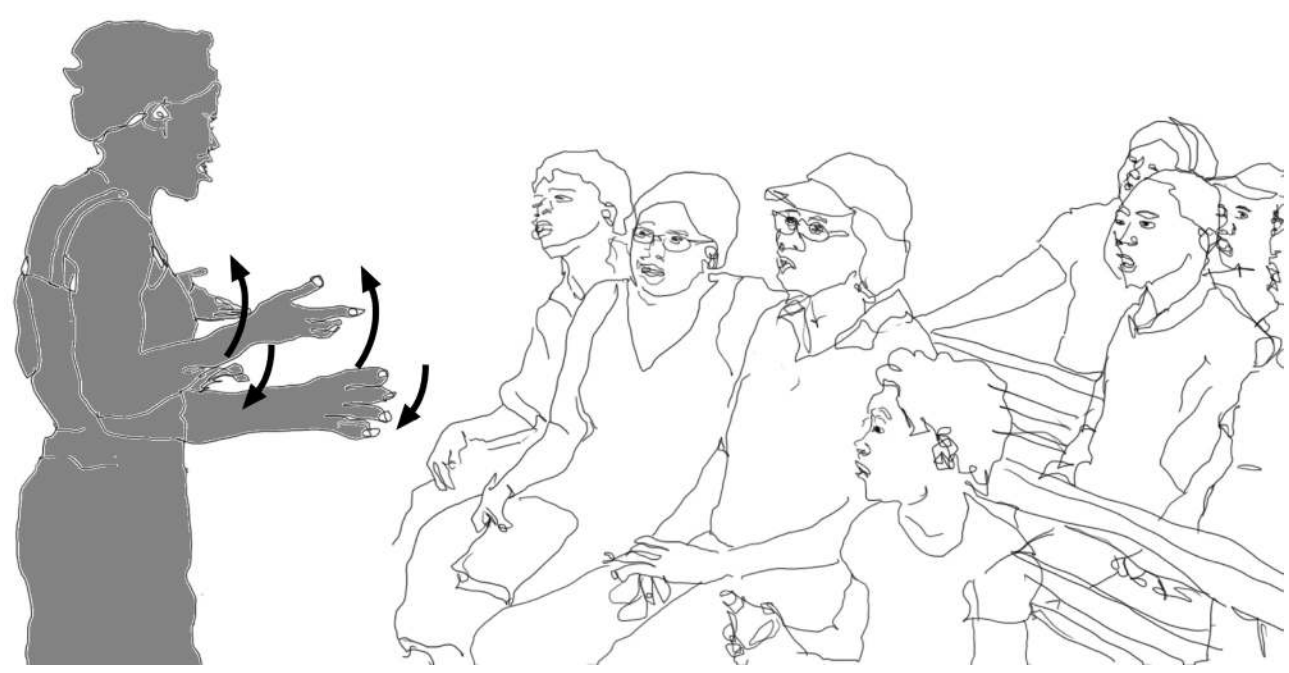

As the participants were from different parishes, one can suppose that after this week, the song was transmitted orally to their respective choirs, accompanied by the same gestures used by the composer.

Choir directors are not the only way in which songs and conducting gestures are disseminated. In recent years, modern communication technologies have become so widespread in Cameroon that almost every adult has a mobile telephone, and these devices are frequently used to make audio and video recordings. Rehearsals and directors are sometimes filmed or recorded so that they can be viewed or listened to again later. This way, people learn songs or notice conducting styles which they in turn pass on to others, without either party needing to know how to read text or music. Moreover, this allows the song learning process to be extended to a very wide range of ages. As shown in Illustration 12, the children of the BAPRESCA choir members were often present during the rehearsals during the week I spent with them, just as young children sometimes come to the rehearsals of the parish choirs. By listening, they learn the repertory and what the 
director's gestures mean, mastering them to the extent that they can mimic the gestures before they have even joined the choir. During the CD recording sessions at the Kumba parish's hall in 2012, I observed a child trying to correctly reproduce the director's gestures on his own, at a distance from the group, which was arranged in a circle around the microphones.

13: Children mimicking the director's gestures during rehearsals

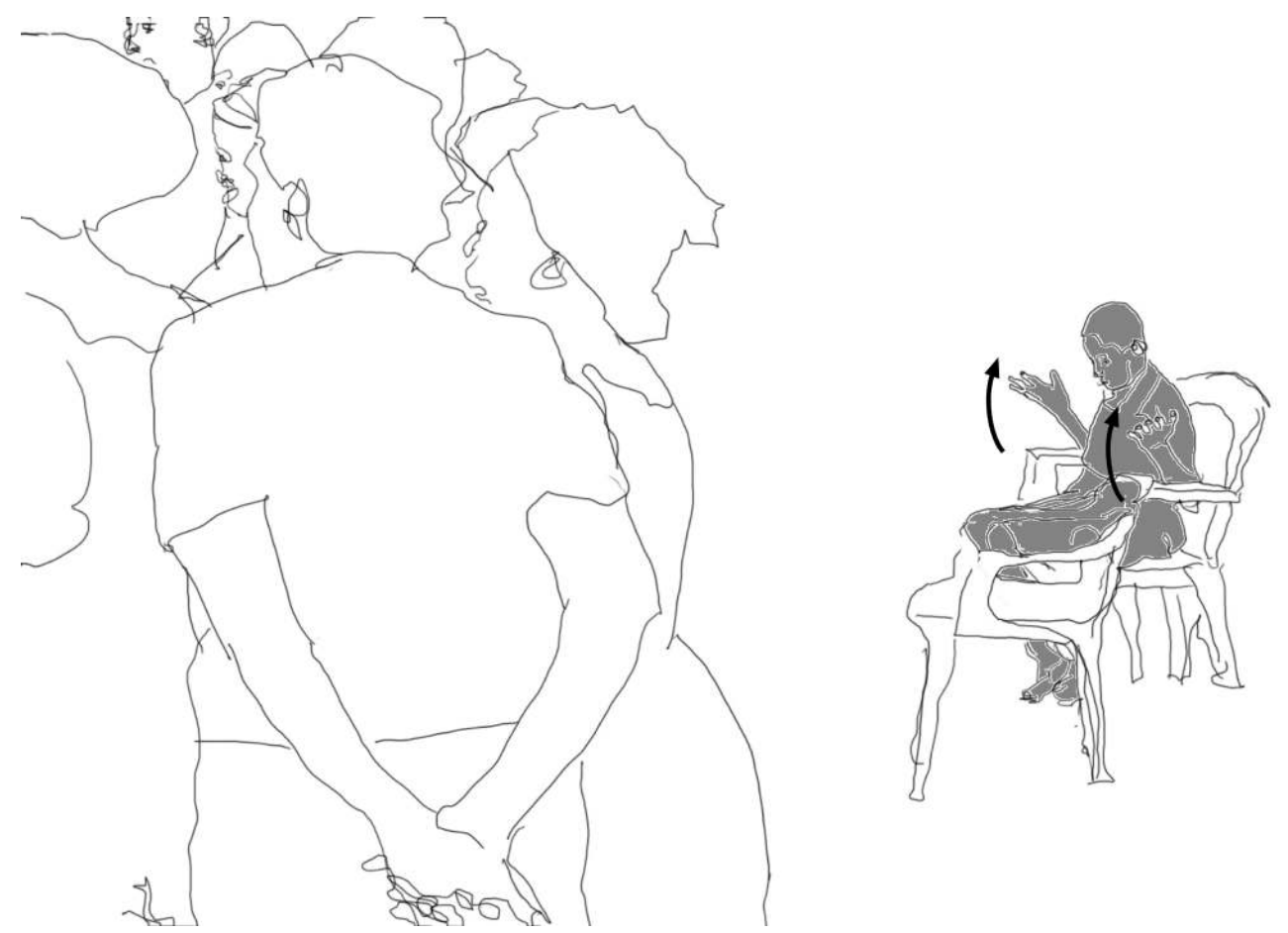

There is no formal training for the function of choir director in the BAPRESCA choirs. This role is generally held by the best soloist singers, or the people who know the songs particularly well. They need to have enough authority to transmit the songs correctly and to firmly direct the choir during public presentations. Once they have technically mastered the songs through observation and imitation, they apply the same techniques in order to teach them to their own choirs. In this process of oral and gestural transmission, the composers or the most gifted choir directors play a key role as personal mediators and models.

\section{Concluding remarks}

Our study of the different choir conducting techniques used in the BAPRESCA choral ensembles in Cameroon has shown that the movements of the musicians' hands and arms, while outwardly appearing to fill a similar function as in Western musical tradition, do not stem from the same principles. In musical cultures which do not make a difference between accented and unaccented beats, marking an accented beat with a downward gesture is unnecessary. Inversely, in Western music, which is generally executed using written scores, a choir director does not need to illustrate the words of the song through gestures. The techniques used in each case are tailored to the respective culture, its communication conventions and the demands and expectations associated with its musical practice. It is for this reason that the BAPRESCA choir directors are not interested 
in using Western choir conducting techniques, which they have access to via television and video recordings. ${ }^{29}$

Moreover, this analysis shows that over the span of the musical process-from the rehearsal phase to public presentation of the songs-a variety of gestural systems can be used. The same choir director may use chironomic gestures during rehearsals and give deictic, rhythmic and metric signals during public presentations, while also seamlessly incorporating dance movements at certain points, or illustrating the words to the song with iconic gestures. The style of each musical execution is determined by the musical and social context. In this regard, there are commonalities between the abilities of choir directors in different cultures. A Western conductor also behaves differently-in terms of both speech and gestures-during rehearsals and public presentations. Only during the former does a conductor do things such as sing the instrumental parts or make arm movements to mimic the playing techniques. Conductors in both cultures assume a more theatrical manner during concerts.

Nevertheless, these analyses also show that although the function of choir director in Cameroon surely emerged with the introduction of Christian church choirs, the role as it has developed does not stem purely from the Mission, nor is it purely the result of cultural colonisation. Cameroonians have incorporated certain practices from the precolonial musical culture into the modern-day techniques used to conduct church choirs-such as the roles of "first singer" and "first dancer" - and they have adapted the function of the choir director to their own needs. The audience's positive response to pronounced gestural accompaniment to the music during the choir competitions shows that the inhabitants of the Bakossi region enjoy this new style and have long considered it an integral part of their musical culture.

\section{BIBLIOGRAPHY}

BAERTSCHI, Friedrich, Jokwele la Elongi, date and origin unknown [Mission 21 archives, Basel].

BAERTSCHI, Friedrich, Madoi ma Sion, Basel, Rotaprint, 1955.

BALZ, Heinrich, Where The Faith Has To Live. Studies in Bakossi society and Religion, Part I: Living

Together, Basel, Basel Mission, 1984.

BALZ, Heinrich, Where The Faith Has To Live. Studies in Bakossi society and Religion, Part II: The Living, The Dead and God, Berlin, Dietrich Reimer, 1995, II, 1: Chap.1 and 2.

BALZ, Heinrich, Where The Faith Has To Live. Studies in Bakossi society and Religion Part II: The Living, The Dead and God, Berlin, Dietrich Reimer, 1995, II, 2: Chap.3 and 4.

BASLER MISSION (ed.), Der Evangelische Heidenbote, 1906/03, Basel, Basel Mission, 1906.

BASLER MISSION (ed.), Jahresbericht der evangelischen Missionsgesellschaft zu Basel 1897, Basel, Basel Mission, 1898.

BASLER MISSION (ed.), Jahresbericht der evangelischen Missionsgesellschaft zu Basel 1899, Basel, Basel Mission, 1900. 
BASLER MISSION (ed.), Jahresbericht der evangelischen Missionsgesellschaft zu Basel 1906, Basel, Basel Mission, 1907.

BASLER MISSION (ed.), Jahresbericht der evangelischen Missionsgesellschaft zu Basel 1925, Basel, Basel Mission, 1926.

BETZ, Rudolf, "Die Trommelsprache der Duala", in DANCKELMANN, Alexander (ed.), Mitteilungen von Forschungsreisenden und Gelehrten aus den deutschen Schutzgebieten vol.11, Berlin, Mittler, 1898, p.1-86.

BOWEN, José Antonio, “The Rise of Conducting”, in BOWEN, José Antonio (ed.), The Cambridge Companion to Conducting, Cambridge, Cambridge University Press, 2003, p.93-113.

COLSON, Jon F., Conducting and Rehearsing the Instrumental Music Ensemble, Lanham, Toronto, Plymouth, Scarecrow Press, 2012.

DORSCH, Heinrich, "Grammatik der Nkosi-Sprache mit einer das Nkosi mit Duala vergleichenden Einleitung”, in MEINHOF, Carl (ed.), Zeitschrift für Kolonialsprachen, Berlin, Dietrich Reimer, 1911, p.241-284.

EJEDEPANG-KOGE, Samuel Ngome, The Tradition of a People Bakossi. A Historical-Socio-Anthropological Study of one of Cameroon's Bantu Peoples [1971], Yaoundé, SOPECAM B.P., 1986.

GUTBROD, Johannes et BAERTSCHI, Friedrich, Myenge ma Ngoso, „Solo-Lieder“ in der Dualasprache [unpublished, Mission 21 archives, Basel], Cameroon, 1912-1914.

HUTTER, Franz, Wanderungen und Forschungen im Nord-Hinterland von Kamerun, Braunschweig, Friedrich Vieweg und Sohn, 1902.

ITTMANN, Johannes, Die Religion im vorderen Kamerun, available online at: http://www.johannesittmann.de/site/band3.htm [consulted on 22 May 2014].

ITTMANN, Johannes and EBDING, Friedrich, "Religiöse Gesänge aus dem nördlichen Waldland von Kamerun”, in SEMINAR FÜR AFRIKANISCHE SPRACHEN DER UNIVERSITÄT HAMBURG (ed.), Afrika und Übersee, Sprachen und Kulturen, Berlin, Reimer, vol.XXIX, 1954-1955, p.169-177 and vol.XL, 1956, p.39-44 and p.125-132.

ITTMANN, Johannes (text) and LIPP, Karl (musical exemples), "Lieder aus dem Kameruner Waldland”, in SEMINAR FÜR AFRIKANISCHE SPRACHEN DER UNIVERSITÄT HAMBURG (ed.), Afrika und Übersee, Sprachen und Kulturen, vol.XLII, 1958, p.1-16 and p.69-80.

KELLER, Werner, Zur Freiheit berufen. Die Geschichte der Presbyterianischen Kirche in Kamerun, Zurich, Theologischer Verlag, 1981.

KENDON, Adam, Gesture. Visible Action as Utterance, Cambridge, Cambridge University Press, 2004.

KING, Roberta, NGOYA KIDULA, Jean et KRABILL, James (eds.), Music in the Life of the African Church , Baylor, Baylor University Press, 2008.

KLEIN, Christopher, Messkompositionen in Afrika. Ein Beitrag zur Geschichte und Typologie der katholischen Kirchenmusik Afrikas, Göttingen, Ed. Re, 1990.

MCNEILL, David, Hand and Mind. What Gestures Reveal about Thought, Chicago, London, University of Chicago Press, 1992.

NICOD, Henri, La Vie mystérieuse de l'Afrique noire, Paris, Payot, 1948.

PRESBYTERIAN CHURCH IN CAMEROON (ed.), The BAPRESCA Song Book, Tombel, CABTAL, 2002.

RIVA, Nepomuk, Handschrift und Körpernotation. Schriftliche und mündliche Überlieferungen von Kirchenmusik in Kamerun, Frankfurt-am-Main, Peter Lang, 2014. 
SCHNEIDER, Marius, "Lieder der Duala”, in VETTER, Walther (ed.), Deutsches Jahrbuch der Musikwissenschaft für 1959, Leipzig, Peters, 1960, p.93-113.

WÄNGLER, Hans-Heinrich, “Über Beziehungen zwischen gesprochenen und gesungenen Tonhöhen in afrikanischen Tonsprachen", in SIMON, Arthur (ed.), Musik in Afrika, Berlin, Museum für Völkerkunde, 1983, p.58-65.

WEBER , Lina, Le Premier rapport de travail, Victoria, 1946 [unpublished, Mission 21 archives, Basel].

WURM, Paul, Die Religion der Küstenstämme in Kamerun, nach Berichten der Missionare Keller, Schuler, Spellenberg, Schürle und Dinkelacker, Basel, Verlag der Missionsbuchhandlung, 1904.

\section{NOTES}

1. The choir group has its own hymn book containing the words to the songs, The BAPRESCA Song Book, published by the Presbyterian Church in Cameroon (Tombel, 2002). It was created thanks to funding from an organisation called CABTAL which has worked for years on producing translations of the Bible into several Cameroonian languages. See http://www.cabtal.org [consulted on 22 May 2014]. Youtube contains videos of several songs sung by BAPRESCA choirs and a filmed interview on the choir group by the author of this article. See "BAPRESCA. Eine Chorgemeinschaft aus West-Kamerun" at the address: http://www.youtube.com/watch? $\mathrm{v}=\mathrm{kVcKm} 4 \mathrm{nN} 6 \mathrm{VU}$ [consulted on 25 May 2014].

2. On the Catholic missionary presence, see for example KLEIN, Christopher, Messkompositionen in Afrika. Ein Beitrag zur Geschichte und Typologie der katholischen Kirchenmusik Afrikas, Göttingen, Ed. Re, 1990. On the general evolution of church music in Africa, see KING, Roberta, NGOYA KIDULA, Jean and KRABILL, James (ed.), Music in the Life of the African Church, Baylor, Baylor University Press, 2008.

3. Analyses of oral transmission via different systems of gestures in the independent choir Bakossi Seraphim Choir, which sings only songs written by the pastor Elias Ebong Ngole can be found in RIVA, Nepomuk, Handschrift und Körpernotation. Schriftliche und mündliche Überlieferungen von Kirchenmusik in Kamerun, Frankfurt-am-Main, Peter Lang, 2014.

4. For their support and hospitality while I was completing my research in the field, I wish to thank the composers Paul Epie Mesumbe and Rey Njume Etone, the president of BAPRESCA, Ekwoge Edward Mbome, Reverend Ngole David of CABTAL, and the various choirs I encountered, notably those from the Tombel, Nyasoso, Ebonji, Muebah, Kumba and Douala parishes.

5. On the history of the PCC, see KELLER, Werner, Zur Freiheit berufen. Die Geschichte der Presbyterianischen Kirche in Kamerun, Zurich, Theologischer Verlag, 1981. On the development of Christianity in the Bakossi region, see BALZ, Heinrich, Where the Faith Has to Live. Studies in Bakossi society and Religion, Part I: Living Together, Basel, Basel Mission, 1984 and Part II: The Living, The Dead and God, II, 1: Chap.1 and 2; Part II: The Living, The Dead and God, Berlin, Dietrich Reimer, 1995, II, 2: Chap. 3 and 4.

6. See BASLER MISSION (ed.), Jahresbericht der evangelischen Missionsgesellschaft zu Basel 1899, Basel, Basel Mission, 1900, p.80.

7. In Doula, there is only one manuscript setting out a simple theory of music, written in the 1920s, but it was probably never used. See BAERTSCHI, Friedrich, Jokwele la Elongi, date and origin unknown [Mission 21 archives, Basel].

8. Song lyrics can be found in ITTMANN, Johannes and EBDING, Friedrich, "Religiöse Gesänge aus dem nördlichen Waldland von Kamerun", in SEMINAR FÜR AFRIKANISCHE SPRACHEN DER UNIVERSITÄT HAMBURG (ed.), Afrika und Übersee, Sprachen und Kulturen, Berlin, Reimer, vol.XXIX, 
1954-1955, p.169-177 and vol.XL, 1956, p.39-44 and p.125-132. The book by BAERTSCHI, Friedrich, Madoi ma Sion (Basel, Rotaprint, 1955), contains a fascicle with scores.

9. BETZ, Rudolf, "Die Trommelsprache der Duala", in DANCKELMANN, Alexander (ed.), Mitteilungen von Forschungsreisenden und Gelehrten aus den deutschen Schutzgebieten, vol. 11, Berlin, Mittler, 1898, p.1-86.

10. For an in-depth study on the dissemination of Tonic Sol-fa in Cameroon, see RIVA, Handschrift und Körpernotation, op. cit., p.163-172.

11. On mulit-part harmony singing, see BASLER MISSION (ed.), Jahresbericht der evangelischen Missionsgesellschaft zu Basel 1897, Basel, Basel Mission 1898, p. 70. On the compositions themselves, see BASLER MISSION (ed.), Jahresbericht der evangelischen Missionsgesellschaft zu Basel 1906, Basel, Basel Mission, 1907, p.85. The missionaries' reports were used to monitor the work being carried out by the Basel Mission, and excerpts were published in periodicals sent to people who provided funding.

12. BASLER MISSION (ed.), Jahresbericht der evangelischen Missionsgesellschaft zu Basel 1925, Basel, Basel Mission, 1926, p.72-73.

13. BASLER MISSION (ed.), Der Evangelische Heidenbote, Basel, Basel Mission, 1906, p.22.

14. WURM, Paul, Die Religion der Küstenstämme in Kamerun, nach Berichten der Missionare Keller, Schuler, Spellenberg, Schürle und Dinkelacker, Basel, Verlag der Missionsbuchhandlung, 1904, p.23.

15. Lina Weber, in her first work report, Victoria, 1946, p.2 [unpublished, Mission 21 archives, Basel].

16. The only scores to Cameroonian songs from the Mission period are found in: GUTBROD, Johannes and BAERTSCHI, Friedrich, Myenge ma Ngoso, „Solo-Lieder“ in der Dualasprache, Cameroon, 1912-1914 [unpublished, Mission 21 archives, Basel]; ITTMANN, Johannes (text) and LIPP, Karl (musical examples), "Lieder aus dem Kameruner Waldland", in SEMINAR FÜR AFRIKANISCHE SPRACHEN DER UNIVERSITÄT HAMBURG (ed.), Afrika und Übersee, Sprachen und Kulturen, vol. XLII, 1958, p.1-16 and p.69-80.

17. See for example WURM, Die Religion der Küstenstämme in Kamerun, nach Berichten der Missionare Keller, Schuler, Spellenberg, Schürle und Dinkelacker, op. cit., p.19-20.

18. Henri Nicod offers detailed descriptions of the dance styles in La Vie mystérieuse de l'Afrique noire, Paris, Payot, 1948, p.142-151.

19. For Akosa grammar, see DORSCH, Heinrich, "Grammatik der Nkosi-Sprache mit einer das Nkosi mit Duala vergleichenden Einleitung”, in MEINHOF, Carl (ed.), Zeitschrift für Kolonialsprachen, Berlin, Dietrich Reimer, 1911, vol.1/04, p.258-259 and p.281.

20. See HUTTER, Franz, Wanderungen und Forschungen im Nord-Hinterland von Kamerun, Braunschweig, Friedrich Vieweg und Sohn, 1902, p.484-487.

21. ITTMANN, JOHANNES, DIE RELIGION IM VORDEREN KAMERUN, P.222, AVAILABLE ONLINE AT: HTTP://WWW.JOHANNES-ITTMANN.DE/SITE/BAND3.HTM [CONSULTED ON 22 MAY 2014].

22. For an overview of the emergence of the conductor in Europe, see for example BOWEN, José Antonio, "The Rise of Conducting", in BOWEN, José Antonio (ed.), The Cambridge Companion to Conducting, Cambridge, Cambridge University Press, 2003, p.93-113.

23. An ample description of the reherasal process within an instrumental ensemble can be found in, for example, COLSON, Jon F., Conducting and Rehearsing the Instrumental Music Ensemble, Lanham, Toronto, Plymouth, Scarecrow Press, 2012.

24. On the precolonial civilisation and musical instruments of Bakossi, see EJEDEPANG-KOGE, Samuel Ngome, The Tradition of a People Bakossi. A Historical-Socio-Anthropological Study of one of Cameroon's Bantu Peoples [1971], Yaoundé, SOPECAM B.P., 1986, p.207, p.211-212.

25. MCNEILL, DAVID, HAND AND MIND. WHAT GESTURES REVEAL ABOUT THOUGHT, CHICAGO, LONDON, UNIVERSITY OF CHICAGO PRESS, 1992.

26. KENDON, Adam, Gesture. Visible Action as Utterance, Cambridge, Cambridge University Press, 2004. 
27. MCNEILL, HAND AND MIND. WHAT GESTURES REVEAL ABOUT THOUGHT, OP. CIT., P.75-82.

28. On the relationship between spoken tone and melody in the music of Cameroon, see WÄNGLER, Hans-Heinrich, "Über Beziehungen zwischen gesprochenen und gesungenen Tonhöhen in afrikanischen Tonsprachen”, in SIMON, Arthur (ed.), Musik in Afrika, Berlin, Museum für Völkerkunde, 1983, p.58-65 or SCHNEIDER, Marius, "Lieder der Duala", in VETTER, Walther (ed.), Deutsches Jahrbuch der Musikwissenschaft für 1959, Leipzig, Peters, 1960, p.93-113.

29. American gospel music, for example, is very popular in Cameroon thanks to television and video, but seeing recordings of the choir directors has not affected the Cameroonians approach to musical practice.

\section{ABSTRACTS}

This article examines how Western-style choir conducting was introduced in Cameroon by the Basel Mission. In analyzing different conducting techniques within a Presbyterian choir organisation in southwest Cameroon, we observe a new take on the function of the choir director, modelled after several aspects of the precolonial musical culture. Moreover, it becomes apparent that the missionaries introduced the role of the choir director only summarily, as Cameroonians have developed their own distinct conducting techniques and gestures. This can be explained by the difference in expectations between a choir director operating in a musical culture characterised by oral tradition and one operating in Western culture. For example, the former uses chironomic gestures to indicate pitch or iconic gestures to remind singers of the words of the song while keeping the rhythm. This study shows that choir conducting styles depend not only on the music, but also on the musical practice within a specific cultural context.

\section{INDEX}

Keywords: Choir director, Iconic gestures, Chironomic gestures, Traditional music, Precolonial music, Church music, BAPRESCA choirs (Cameroon), Choir competitions, Presbyterian Church in Cameroon (PCC), Basel Mission

\section{AUTHORS}

\section{NEPOMUK RIVA}

Nepomuk Riva (born 1974) studied musicology and Protestant theology at Ruprecht-Karl University in Heidelberg and Humboldt University in Berlin. He wrote his doctoral dissertation on the oral and written church music traditions in Cameroon. He has taught ethnomusicology in Berlin and initiated a project on conductor-orchestra communication. He also works as a freelance editor for German television and produces documentaries. 